Gi respons på artikler gjennom artiklenes kommentarfelt på tidsskriftet.no.

Innleggene publiseres fortløpende på Tidsskriftets nettside og et utvalg

av innleggene publiseres også i papirutgaven i spalten «Brev til redaktøren».

Redaksjonen forbeholder seg retten til å foreta redaksjonelle endringer.

Forfattere av vitenskapelige artikler har tilsvarsrett, jf. Vancouver-gruppens regler.

\section{Re: VAS - visuell analog skala}

Subjektive plager eller symptomer kan måles med psykometriske skalaer. Skalaene kan være visuelle eller verbale. Kashif Wagae Faiz omtalte VAS (Visuell analog skala) i nr. 3/2014 av Tidsskriftet (1). Jan Kolflaath presiserer temaet i nr. 10/2014 (2): VAS er en ugradert angivelse $(0-100 \mathrm{~mm})$ på en linjal med økende bredde for økende smerte, mens NRS (= numeric rating scale) er gradert ved bruk av tall fra 1-10 langs en strek/linjal. VAS har større statistisk styrke (2). Kolflaath omtalte imidlertid ikke den statistiske styrken til VNRS (= verbal numeric rating scale) versus VAS. Dette reiser spørsmålet om hvilken metode som skal velges til bruk i fremtidens forskning, bl.a. fordi VNRS er enklere i klinisk bruk ved at pasienten muntlig angir et tall mellom $0-10$.

I en studie av Holdgate og medarbeidere konkluderes det med at VAS og VNRS korrelerte godt når det gjaldt endringer i smerter $(\mathrm{r}=0.95,95 \%$ CI 0.94-0.96) (3). VNRS var signifikant høyere enn VAS for parede observasjoner, hvor $95 \%$ av forskjellene mellom VAS og VSNR lå mellom $-2,3 \mathrm{og} 1,3 \mathrm{~cm}$. Pasientene scoret sine smerter systematisk høyere på VNRS.

Både VAS og VNRS er egnet til å tallfeste endringer hos den enkelte pasient, men mindre egnet til å sammenligne ulike pasienter. Siden pasientene scorer sine smerter systematisk høyere på VNRS sammenlignet med VAS, må man holde seg til én av metodene.

Internasjonalt har VNRS økende utbredelse, kanskje mest fordi metoden er enkel i bruk. Pasienten kan spørres der og da uten behov for ekstra utstyr. Mens VAS-registrering krever opplæring, er den pedagogiske utfordring mindre med VNRS, spesielt i de tilfeller hvor man gjør undersøkelsen via brev eller ved telefonintervju.

I den kliniske hverdagen ønsker man også enkle metoder for god smerteangivelse. Jo enklere metoden er, jo større sjanse er det for at metoden blir brukt. Her har VNRS en klar fordel fremfor VAS eller NRS. I forskningsøyemed er det også en stor fordel om man kan bli enige om en metode som brukes rutinemessig i klinikken, spesielt med tanke på retrospektive studier og studier med stort antall pasienter og/eller data.

\section{Stein Tyrdal \\ stein.tyrdal@ous-hf.no \\ Johan Ræder}

Stein Tyrdal (f. 1956) er dr.med. og overlege ved Overekstremitetsseksjonen, Ortopedisk avdeling, Oslo universitetssykehus.

Ingen oppgitte interessekonflikter.

Johan Ræder (f. 1954) er overlege ved Avdeling for anestesiologi, Oslo universitetssykehus og professor ved Institutt for Klinisk Medisin, Universitetet i Oslo.

Ingen oppgitte interessekonflikter.

\section{Litteratur}

1. Faiz KW. VAS - visuell analog skala. Tidsskr Nor Legeforen 2014: 134: 323 2. Re KJ. VAS - visuell analog skala. Tidsskr Nor Legeforen 2014; 134: 1019.

3. Holdgate A, Asha S, Craig J et al. Comparison of a verbal numeric rating scale with the visual analogue scale for the measurement of acute pain. Emerg Med (Fremantle) 2003; 15: 441-6.

\section{Re: Skråblikk fra et sykehusmottak}

Lilleås præsenterede en trist, men velskrevet tekst om den organisatoriske tilstand på et norsk sygehus i Tidsskriftet nr. 3/2015(1). Desværre er billedet ikke stort anderledes end det man kan finde på mange danske sygehuse. Administrative og økonomiske logikker har taget over på områder som tidligere var styret ud fra en sundhedsprofessionel logik. Eller sagt med andre ord, den professionelle dømmekraft sættes mere og mere ud af kraft til fordel for retningslinjer, økonomihensyn og indikatorer. Resultatet er, at de patienter som ikke passer ind i en administrativ/økonomisk forstilling om sygdom kan risikere at få en meget nødtørftig behandling.

Det er vigtige iagttagelse der opridses af Lilleås i disse hverdagsnoter. Samme billede tegnes i min bog om styringssystemernes betydning for den konkrete patientbehandling $(2,3)$. Vi ved at bedre inddragelse af patienterne kan gøre en verden til forskel, men vi gør det modsatte i sundhedsvæsenet. Vi taler mere og mere om patienten som inddraget partner, men i realiteten bruger vi styringssystemer som tenderer at gøre det modsatte. Mange af de øjeblikkelige problemer er skabt af de styringssystemer der var tiltænkt at være nemme løsninger på gårsdagen problemer. Vi bør sætte et langt mere kritisk lys på disse styringssystemer, eller om man vil institutionelle udviklinger.

\section{Erik Riiskjær}

erik.riiskjaer@stab.rm.dk

Erik Riiskjær (f. 1951) er chefkonsulent ved CFK-Folkesundhed og kvalitetsudvikling.

Ingen oppgitte interessekonflikter.

\section{Litteratur}

1. Lilleås E. Skråblikk fra et sykehusmottak. Tidsskr Nor Legeforen 2015; 135 : $266-7$.

2. Riiskjær E. Patienten som partner. En nødvendig idé med ringe plads. Odense: Syddansk Universitetsforlag, 2014.

3. Gulbrandsen P. En dansk økonom ser på helsetjenesten. Tidsskr Nor Legeforen 2015; 135: 355

\section{Re: Skriftlig legemiddelreklame - fremdeles ikke til å stole på?}

Lars Slørdal og medarbeideres artikkel om påstander i legemiddelreklame (1) er ikke objektiv fordi det er en manglende sammenheng mellom resultatene og det «budskapet» som formidles (2). Forfatterne påstår at bare primære endepunkter (sykelighet/dødelighet) skal formidles i reklamen (3). Legemiddeldirektivet påpeker tvert imot at utsagn kan gis, dersom disse supplerer, bekrefter eller presiserer de primære opplysningene gitt i preparatomtalen (SPC) (4). Steinar Madsen \& Bente Jerkø påpeker i en kommentarartikkel i Tidsskriftet at deres vurdering av muntlig legemiddelreklame er i overensstemmelse med Slørdal og medarbeideres funn (5). Har de lest artikkelen og vurdert den i henhold til Legemiddelverkets direktiv?

Det finnes en omfattende og entydig forskningslitteratur som tilsier at interessekonflikter i form av industrirelasjoner øker sannsynligheten for konklusjoner i favør av sponsor (3). Dette åpner for mange teorier. Fremfor alt mener jeg funnet kan være forenlig med at de som har nøye kunnskap om et medikament, fra basalforsk- 
ningen til den kliniske utprøvningen, er best skikket til å vurdere medikamentets nytte.

Jeg frykter for at innholdet i artikkelen til Slørdal og medarbeidere er preget av en holdning hvor en på et generelt grunnlag bidrar til å så tvil om forskning gjennomført i regi av eller i samarbeid med legemiddelindustrien. Problemstillingen er allerede godt beskrevet (6): «.. the conflict of interest (COI) .. movement's instigators have produced no solid evidence of harm commensurate with their extravagant allegations. ... they have diverted resources away from more worthwhile pursuits, such as basic and applied medical research, clinical care and medical education towards onerous compliance exercises and obtrusive laws. .., they have made it respectable to ignore the epistemological foundations of medical science, diverting attention away from the scientific merit of the information presented and focusing it instead on the identity and motives of those who present the information.»

At noen tidsskrifter, som $B M J$, ikke vil lytte til kommentarer fra personer med tilknytning til noen av medisinens viktigste forskningsinstitusjoner, fremmer neppe kvalitet. Vil ikke slike regler være i strid med ytringsfrihet?

\section{Arne Høiseth}

arnhois@online.no

Arne Høiseth (f. 1944) er pensjonert radiolog.

Oppgitte interessekonflikter: Utprøver i fase III legemiddelutprøvinger

\section{Litteratur}

1. Gladsø KH, Garberg HR, Spigset 0 et al. Skriftlig legemiddelreklame - fremdeles ikke til å stole på? Tidsskr Nor Legeforen 2014; 134: 1563-8.

2. Høiseth A. Re: Skriftlig legemiddelreklame - fremdeles ikke til å stole på? Tidsskr Nor Legeforen 2015; 135: 212

3. Slørdal L, Spigset O, Garberg HR et al. L. Slørdal og medarbeidere svarer Tidsskr Nor Legeforen 2015: 135: 212-3.

4. Statens legemiddelverk. Legemiddelreklame skal utformes i samsvar med godkjent preparatomtale (SPC). www.legemiddelverket.no/Godkjenning_og_ regelverk/reklame/reklamesamsvarspc/Sider/default.aspx (22.2.2015).

5. Madsen S, Jerkø B. Sviktende kvalitet på muntlig legemiddelreklame. Tidsskr Nor Legeforen 2015: 135: 110-1.

6. Barton D, Stossel T, Stell L. After 20 years, industry critics bury skeptics, despite empirical vacuum. Int J Clin Pract 2014; 68: 666-73.

\section{Slørdal og medarbeidere svarer:}

Vi skal spare så vel Arne Høiseth som Tidsskriftets øvrige lesere for imøtegåelser av alle de momenter førstnevnte tar til torgs i sitt innlegg, men kommer ikke utenom noen presiseringer:

Vi har aldri hevdet at «bare primære endepunkter (sykelighet/ dødelighet) skal formidles i reklamen», men har vist til legemiddelforskriftens krav om at reklamen skal være nøktern, saklig og ikke gi et overdrevet bilde av et legemiddels medisinske verdi (1). Vi forstår, som allerede nevnt $i$ vårt forrige svar til Høiseth (2), at meningene om hva som er nøkternt og saklig kan divergere, men fastholder våre funn - slik vi også fastholder at resultater og konklusjon i artikkelen vår (3) samsvarer.

Vi har ingen problemer med å være enig med Høiseth i at «de som har nøye kunnskap om et medikament (.....) er best skikket til å vurdere medikamentets nytte». Hvordan dette utsagnet kan presenteres som utledet fra det vi vet om effekten av interessekonflikter, går over vår forstand.

Vårt fokus var legemiddelindustriens skriftlige reklamemateriell, og ikke «forskning gjennomført i regi av eller samarbeid med legemiddelindustrien». Hvis Høiseth med bruk av sitatet fra Barton et al. (4) vil mene at vi er en del av en interessekonfliktbevegelse som avleder ressurser fra forskning, pasientbehandling og utdanning og ignorerer framskritt og vitenskapelig informasjon, skal vi ha rygg til å bære en slik karakteristikk. Men da må vi også be om forståelse for at dette er et debattnivå vi ikke ønsker å ferdes på.

Redaksjonen i $B M J$ har ikke bestemt seg for å innskrenke aktiviteten i tidsskriftets spalter for «personer med tilknytning til noen av medisinens viktigste forskningsinstitusjoner», men for individer med interessekonflikter i form av bindinger til kommersielle interessenter (5). Vi begriper ikke hvordan dette kan være «i strid med ytringsfrihet». Når ble kjøp av innflytelse en menneskerett?

\section{Lars Slørdal \\ Lars.Slordal@ntnu.no \\ Olav Spigset \\ Hedda Rosland Garberg \\ Kristin Haugen Gladsø}

Lars Slørdal (f. 1955) er spesialist i klinisk farmakologi, professor ved Institutt for laboratoriemedisin, barne- og kvinnesykdommer, Norges teknisk-naturvitenskapelige universitet og overlege ved Avdeling for klinisk farmakologi, St. Olavs hospital.

Ingen oppgitte interessekonflikter.

Olav Spigset (f. 1963) er spesialist i klinisk farmakologi, overlege ved Avdeling for klinisk farmakologi, St. Olavs hospital og professor ved Institutt for laboratoriemedisin, barne- og kvinnesykdommer, Norges teknisk-naturvitenskapelige universitet.

Ingen oppgitte interessekonflikter.

Hedda Rosland Garberg (f. 1986) er turnuslege ved Sykehuset Østfold. Ingen oppgitte interessekonflikter.

Kristin Haugen Gladsø (f. 1988) er turnuslegevikar ved Sykehuset Østfold. Ingen oppgitte interessekonflikter.

\section{Litteratur}

1. Legemiddelforskriften. Oslo: Helse- og omsorgsdepartementet, 2009. https://lovdata.no/dokument/SF/forskrift/2009-12-18-1839?q= Legemiddelforskriften (5.3.2013).

2. Slørdal L, Spigset O, Garberg HR et al. L. Slørdal og medarbeidere svarer. Tidsskr Nor Legeforen 2015; 135: 212-3

3. Gladsø KH, Garberg HR, Spigset 0 et al. Skriftlig legemiddelreklame - fremdeles ikke til å stole på? Tidsskr Nor Legeforen 2014; 134: 1563-8.

4. Barton D, Stossel T, Stell L. After 20 years, industry critics bury skeptics, despite empirical vacuum. Int J Clin Pract 2014; 68: 666-73.

5. Chew M, Brizzell C, Abbasi K et al. Medical journals and industry ties. BMJ 2014 349: g7197.

\section{Re: Paradoksal virkning av kunstige søtningsmidler}

Når forfatterne av studien som omtales i denne nyhetssaken (1) fant en korrelasjon mellom inntak av kunstig søtning og markører for metabolsk syndrom og diabetes, så føyer dette seg inn i rekken av tilsvarende funn i andre observasjonelle studier. I en metaanalyse publisert i fjor (2) ble det gjort separate analyser av observasjonsstudier og intervensjonsstudier, hvor forfatterne fant at der kunstig søtning kom negativt ut i observasjonsstudiene, kom de samme søtstoffene udelt positivt ut $\mathrm{i}$ intervensjonsstudiene på parametre knyttet til vekt og kroppssammensetning.

I en lederartikkel som fulgte denne metaanalysen (3) konkluderes det med at per nå, på bakgrunn av det vi vet i dag, bør vi anbefale å velge kunstig søtning fremfor sukkersøtet drikke. Selvfølgelig må vi være åpne for at vi i fremtiden kan finne ut at det store bildet var noe mer komplisert, noe for eksempel den aktuelle studien fra Suez og medarbeidere kan være en indikasjon på. Men inntil videre mener jeg rådene bør gis på bakgrunn av dagens opparbeidede kunnskap.

Trenden de siste årene er at konsumet av sukkerbrus reduseres til fordel for lettbrus (4), og det er fortsatt et mål at inntaket av sukkerbrus reduseres ytterligere. Jeg håper ikke disse nye funnene fører til at denne trenden snur. Det vil med stor sannsynlighet slå negativt ut for folkehelsen.

\section{Vegard Lysne}

vegard.lysne@helse-bergen.no 